\title{
The sequence of lanugo pattern development on the trunk wall in human fetuses
}

\author{
Zygmunt Domagała, A, C-E, Paweł Dąbrowski ${ }^{1, C}$, Wiesław Kurlejej, A, B, Michał Porwolik, , \\ Stawomir Woźniak ${ }^{11, C, E}$, Ryszard R. Kacałaํ, C, E, Bohdan Gworys ${ }^{1, A, B, E, F}$ \\ ${ }^{1}$ Department of Anatomy, Wroclaw Medical University, Poland \\ ${ }^{2}$ Department of Oral Anatomy, Wroclaw Medical University, Poland \\ A - research concept and design; $\mathrm{B}$ - collection and/or assembly of data; $\mathrm{C}$ - data analysis and interpretation; \\ $D$ - writing the article; $E$ - critical revision of the article; $F$ - final approval of article
}

\author{
Address for correspondence \\ Paweł Dąbrowski \\ E-mail: pawel.dabrowski@umed.wroc.pl \\ Funding sources \\ None declared \\ Conflict of interest \\ None declared

\section{Acknowledgements} \\ The authors would like to thank Maksim Plikus \\ (University of Southern California) for his comments \\ and enormous patience, as well as dr Bartosz Milewski \\ (Academy of Fine Arts in Kraków) for preparing the \\ final figures.
}

Received on November 23, 2015

Revised on December 3, 2015

Accepted on January 19, 2016

\begin{abstract}
Background. Due to a growing interest in developmental disorders, and in the long-term skin appendage diseases, both in the cosmetic industry and among specialists in dermatology (broadly defined), there is an increasing number of papers on hair development. The publications by the present team of authors are part of this trend.

Objectives. The aim of the study was to describe the topography and typology of skin pilosity patterns in human fetuses.

Material and methods. A total of 278 fetuses (141 male and 137 female) were qualified for the study. The gestational age ranged from 69 to 226 days after conception. All fetuses were taken from a local collection.

Results. The study revealed that the first single hairs occur on the posterior wall of the trunk in the $17^{\text {th }}$ week of fetal life, and on the anterior wall between the $18^{\text {th }}$ and $19^{\text {th }}$ week. It was found that in human fetuses lanugo appears statistically significantly later on the skin of the anterior of the trunk than on its posterior. The difference in absolute time is almost 2 weeks of fetal life. No other differences were found in the development cycle of lanugo on the anterior and posterior walls of the trunk. A full pattern was first observed on the posterior wall of the trunk in a fetus in the $19^{\text {th }}$ week, and on the anterior wall in the $21^{\text {st }}$ week. It was found that the process of lanugo development was completed on the posterior wall in the $23^{\text {rd }}$ week, and on the surface of the abdomen in the $26^{\text {th }}$ week.
\end{abstract}

Conclusions. The lanugo developmental cycle, consisting in the appearance of the first single hairs, then partial hair and subsequently the formation of final patterns, is the same on both walls of the trunk.

Key words: lanugo, human fetuses, hair pattern, hair development

DOI

10.17219/acem/61440

\section{Copyright}

Copyright by Author(s)

This is an article distributed under the terms of the

Creative Commons Attribution Non-Commercial License

(http://creativecommons.org/licenses/by-nc-nd/4.0/) 
Lanugo is a form of human pilosity in prenatal ontogenesis. It is the first developmental form of hair, usually unpigmented, which is softer and gentler than the later types referred to as vellus and pili. ${ }^{1}$

Due to the considerable interest in developmental disorders and skin appendage diseases in the cosmetic industry and among physicians specializing in dermatology, there has been a growing number of scientific works concerning hair development. ${ }^{4-6}$ The present authors' previous publications on the topography and typology of human fetal hair patterns are part of that trend. ${ }^{2,3} \mathrm{Re}-$ viewers, editors and scientists who commented on those works encouraged further study to determine the exact time when fetal pilosity appears on the trunk. ${ }^{2}$

Available literature data on this subject are scarce and inaccurate. Ludwig only states that lanugo patterns are "clear and explicit" in fetuses at the $5^{\text {th }}-6^{\text {th }}$ month of gestation. ${ }^{7}$ According to Muller et al., fetal hair begin to develop at the early embryological stages, presumably between the $9^{\text {th }}$ and $12^{\text {th }}$ week of pregnancy. ${ }^{8}$ Irmak et al. noticed that when the adrenal cortex starts to produce dehydroepiandrosterone sulfate (DHEA-S) at the early stage of pregnancy $\left(8^{\text {th }}-10^{\text {th }}\right.$ week), the initiation of hair and sebaceous gland differentiation follows. ${ }^{9}$

The sebaceous glands secrete an oily substance called sebum. It mixes with exfoliated epidermal cells to form vernix caseosa, which protects the embryonic skin from the direct influence of the amniotic fluid. Androgen production in the adrenal glands is reduced to a minimal level shortly after labor, which results in lanugo hair loss and sebaceous gland shrinkage.

The aim of this study was to provide a precise and objective assessment of when lanugo hair patterns first appear on the trunk of the human fetus.

\section{Material and methods}

The study was carried out on a collection of fetuses from Department of Normal Anatomy, Wroclaw Medical University (Poland). A total of 278 fetuses (141 males, 137 females) were qualified for the study. The gestational age ranged from 69 to 226 days after conception. All the fetuses investigated had complete case histories and no malformations.

Basic anthropological measurements were made (using Mitutoyo digital calliper 500-709-11, IP67, Kabushiki Kaisha Mitsutoyo, Kanagawa, Japan) to determine the precise morphological age of all the fetuses (Table 1).

In a previous study 3 main types of human lanugo patterns on the anterior trunk wall were defined: the cross pattern (Fig. 1), thoracic whorl pattern (Fig. 2) and abdominal whorl pattern (Fig. 3); 2 main types of lanugo patterns on the posterior trunk wall were also identified: the vertebral column path pattern (Fig. 4) and whorl pattern. ${ }^{3}$

STATISTICA PL software (StatSoft Polska, Kraków,
Poland) was used for that statistical analysis. The analysis of the level of dimorphic differences using the $\chi^{2}$ independence test did not reveal any statistical significance. Therefore, all the material could be analyzed together, without any gender differentiation.

The photographs were taken with a Sony Alpha 37 camera (Sony Corp., Tokyo, Japan) with a Kenko automatic extension tube set (Kenko Co. Ltd., Tokyo, Japan) and a Minolta AF 28-80 zoom lens (Konica Minolta Inc., Tokyo, Japan).

\section{Results}

The results of the study indicate that the appearance of lanugo patterns proceeds similarly in all the types that have been distinguished. No differences were found in the time of appearance of different lanugo patterns of varying degrees of complexity. Hair growth occurs in a certain rhythm, distinctive for both the anterior and posterior walls of the trunk.

The study results allowed fetal hair growth to be assessed from the time of its appearance on the skin surface to the final lanugo pattern formation. Four phases of lanugo development were distinguished:

- No visible lanugo (Fig. 5);

- Trace hair: isolated hairs about $1 \mathrm{~mm}$ long, fastened obliquely; no hair streams; their arrangement is disordered and their length is slightly diverse (Fig. 6);

- Partial pattern: hair is arranged in non-continuous streams forming fragments of patterns; hair length undergoes further differentiation and some single hairs reach over $15 \mathrm{~mm}$;

- Complete pattern: complete patterns are visible regardless of the type (Fig. 7, 8).

\section{Anterior trunk wall}

No lanugo is found on the anterior trunk wall until the end of the $4^{\text {th }}$ month of fetal life (Table 2). The first vestigial hair appears in a fetus on the $128^{\text {th }}$ day of pregnancy. This type of hair was found in 5 fetuses in the $5^{\text {th }}$ month of pregnancy (7.9\%). In this age group, 5 cases of the incomplete cross pattern and 4 cases of the complete cross pattern (including 1 case with the whorl pattern) were observed. The cross patterns were found in fetuses between the $135^{\text {th }}$ and $140^{\text {th }}$ day of fetal life. A lack of hair was found in 7 fetuses and trace hair in 4 fetuses in the $6^{\text {th }}$ month of pregnancy; their age ranged from 141 to 150 days after conception. No hairless fetuses were found in the study population beyond the $150^{\text {th }}$ gestational day. Partial and complete patterns occurred in 51 fetuses at the age over 150 days after fertilization. This constitutes $82.5 \%$ of the study population in the $6^{\text {th }}$ month of fetal life. They were predominantly the cross pattern, with isolated cases of the whorl pattern and the cross pattern 
Table 1. Basic characteristics of the study group

\begin{tabular}{|c|c|c|c|c|c|c|}
\hline $\begin{array}{l}\text { No. of } \\
\text { fetuses }\end{array}$ & $\begin{array}{c}\text { Mean menstruation } \\
\text { age [days] (SD) }\end{array}$ & $\begin{array}{l}\text { v-pl [mm] } \\
\text { (SD) }\end{array}$ & $\begin{array}{l}\text { v-tub [mm] } \\
\text { (SD) }\end{array}$ & $\begin{array}{l}\text { Body mass }[\mathrm{g}] \\
\text { (SD) }\end{array}$ & $\begin{array}{c}\text { Mean morphological } \\
\text { age [days] }\end{array}$ & $\begin{array}{l}\text { Age } \\
\text { [days] }\end{array}$ \\
\hline 25 & $75.5(5.83)$ & $78.0(18.33)$ & $61.0(14.97)$ & $28.6(10.24)$ & 77.0 & $56-84$ \\
\hline 53 & $101.9(8.40)$ & $128.9(29.61)$ & $95.3(20.05)$ & $61.6(31.76)$ & 103.4 & $85-112$ \\
\hline 63 & $127.4(7.19)$ & $199.1(25.10)$ & $140.9(17.23)$ & $198.8(65.18)$ & 129.1 & $113-140$ \\
\hline 63 & $157.7(8.19)$ & $265.4(26.61)$ & $186.3(17.49)$ & $538.5(132.66)$ & 156.0 & $141-168$ \\
\hline 38 & $176.4(7.68)$ & $312.1(22.45)$ & $214.3(17.10)$ & $882.8(164.92)$ & 178.2 & 169-196 \\
\hline 36 & $234.5(9.46)$ & $253.3(35.43)$ & $245.0(24.83)$ & $1017.7(279.39)$ & 235.5 & $197-256$ \\
\hline
\end{tabular}

SD - standard deviation; v-pl - vertex:plantare length; v-tub - vertex:tuberale length.

Table 2. Time of the appearance of lanugo patterns on the anterior wall of the trunk in human fetuses

\begin{tabular}{|c|c|c|c|c|c|c|c|c|c|}
\hline \multirow{2}{*}{$\begin{array}{l}\text { Age } \\
\text { [days] }\end{array}$} & \multirow{2}{*}{$\begin{array}{l}\text { No. of } \\
\text { fetuses }\end{array}$} & \multicolumn{2}{|c|}{ No lanugo } & \multicolumn{2}{|c|}{ Trace hair } & \multicolumn{2}{|c|}{ Partial pattern } & \multicolumn{2}{|c|}{ Complete pattern } \\
\hline & & $\mathrm{n}$ & $\%$ & $\mathrm{n}$ & $\%$ & $\mathrm{n}$ & $\%$ & $\mathrm{n}$ & $\%$ \\
\hline $69-84$ & 25 & 25 & 100 & & & & & & \\
\hline $85-112$ & 53 & 53 & 100 & & & & & & \\
\hline $113-140$ & 63 & 49 & 77.9 & 5 & 7.9 & 5 & 7.9 & 4 & 6.3 \\
\hline $141-168$ & 63 & 7 & 11.1 & 4 & 6.4 & 21 & 33.3 & 31 & 49.2 \\
\hline 169-196 & 38 & & & & & 10 & 26.3 & 28 & 73.7 \\
\hline $197-226$ & 36 & & & & & & & 36 & 100 \\
\hline SUM & 278 & 134 & 48.3 & 9 & 3.2 & 36 & 12.9 & 99 & 35.6 \\
\hline
\end{tabular}

Fig. 1. Diagram of the cross pattern on the anterior wall of the thorax

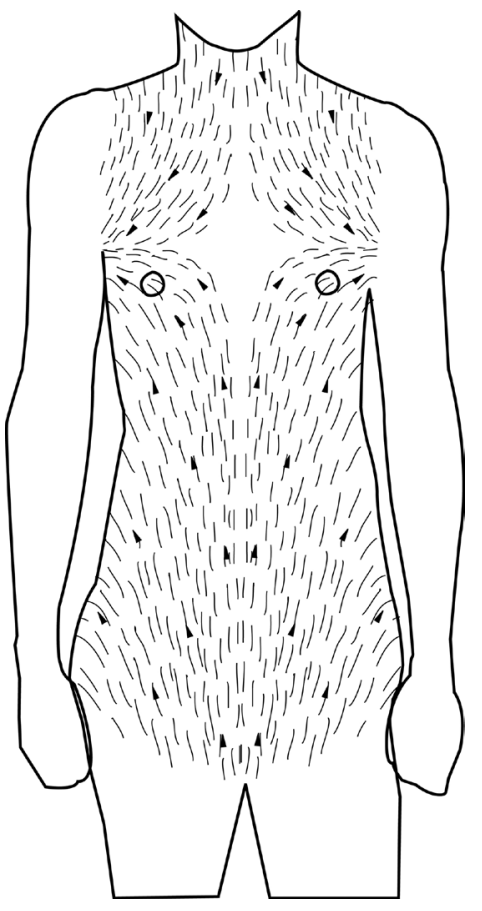

Fig. 2. Diagram of the thoracic whorl pattern on the anterior wall of the thorax

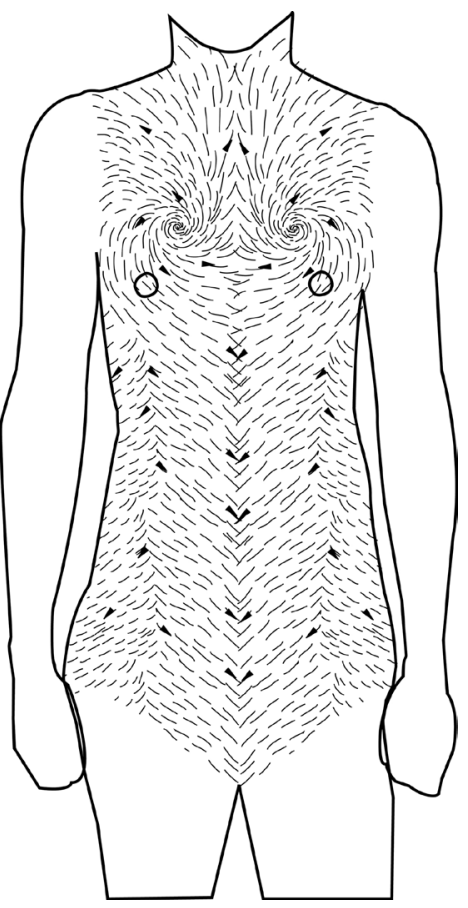


Table 3. Time of the appearance of lanugo patterns on the posterior wall of the trunk in human fetuses

\begin{tabular}{|c|c|c|c|c|c|c|c|c|c|}
\hline \multirow{2}{*}{$\begin{array}{l}\text { Age } \\
\text { [days] }\end{array}$} & \multirow{2}{*}{$\begin{array}{l}\text { No. of } \\
\text { fetuses }\end{array}$} & \multicolumn{2}{|c|}{ No lanugo } & \multicolumn{2}{|c|}{ Trace hair } & \multicolumn{2}{|c|}{ Partial pattern } & \multicolumn{2}{|c|}{ Complete pattern } \\
\hline & & $\mathrm{n}$ & $\%$ & $\mathrm{n}$ & $\%$ & $\mathrm{n}$ & $\%$ & $\mathrm{n}$ & $\%$ \\
\hline $69-84$ & 25 & 25 & 100 & & & & & & \\
\hline 85-112 & 53 & 53 & 100 & & & & & & \\
\hline $113-140$ & 63 & 43 & 68.3 & 6 & 9.5 & 7 & 11.1 & 7 & 11.1 \\
\hline $141-168$ & 63 & 7 & 11.1 & 4 & 6.4 & 21 & 33.3 & 31 & 49.2 \\
\hline 169-196 & 38 & & & & & & & 38 & 100 \\
\hline $197-226$ & 36 & & & & & & & 36 & 100 \\
\hline SUM & 278 & 128 & 46.0 & 10 & 3.6 & 28 & 10.2 & 112 & 40.2 \\
\hline
\end{tabular}

Fig. 3. Diagram of the abdominal whorl pattern on the anterior wall of the thorax

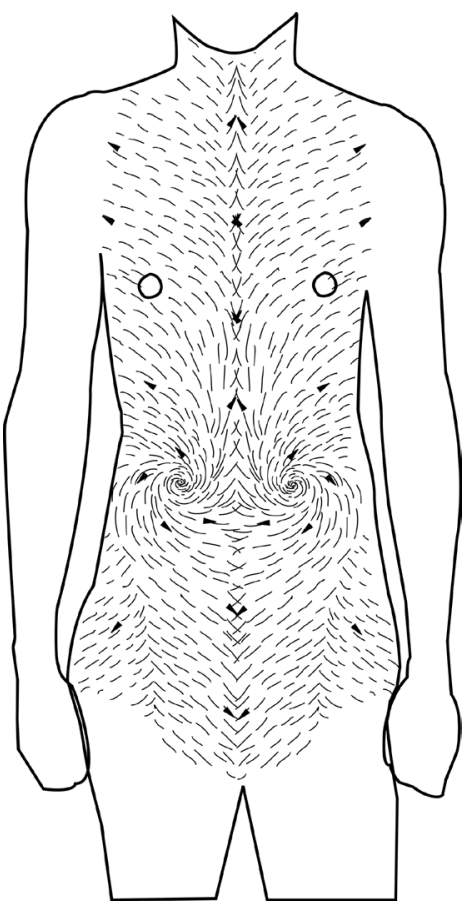

with whorls. In all the fetuses examined, lanugo formed patterns on the anterior wall of the trunk from the $7^{\text {th }}$ month of fetal life. In $25 \%$ of the cases these patterns are incomplete. Complete patterns were found in the fetuses from the $26^{\text {th }}$ week of fetal life.

\section{Posterior trunk wall}

As with the anterior wall, there was no presence of lanugo on the posterior wall in the first two age brackets (i.e., up to 84 days and 85-112 days). The first single lanugo hairs appear on the $116^{\text {th }}$ day of pregnancy. It is significantly earlier than on the anterior wall ( $\chi^{2}$ test; $\left.p<0.05\right)$.
Fig. 4. Diagram of the vertebral column path pattern on the anterior wall of the thorax

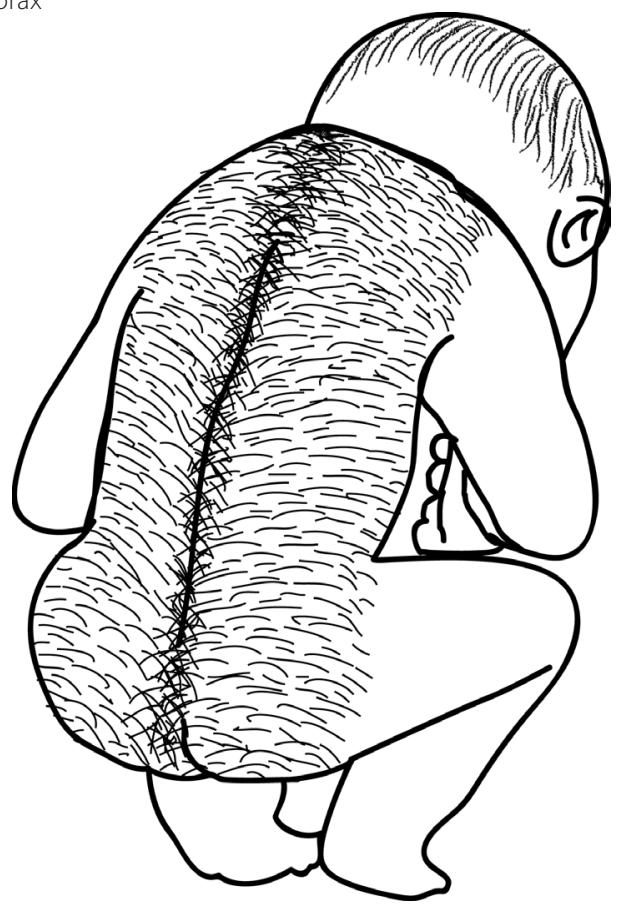

A partial vertebral column path was first observed in a fetus in the $129^{\text {th }}$ day of pregnancy. Altogether, lanugo patterns were present in $22.2 \%$ of the 5 -month fetuses. A predominance of the vertebral column path was observed; single-whorl patterns are numerous and multi-whorl patterns are rare. From the $156^{\text {th }}$ day of pregnancy, i.e. from the end of the $6^{\text {th }}$ month, complete hair patterns were found on the posterior trunk wall. This was significantly earlier than on the anterior trunk wall. A detailed analysis of the time of hair appearance is presented in Table 3. 
Fig. 5. A photo of a fetus without visible lanugo (fetus no. A-1016, morphological age: 5 months after conception)

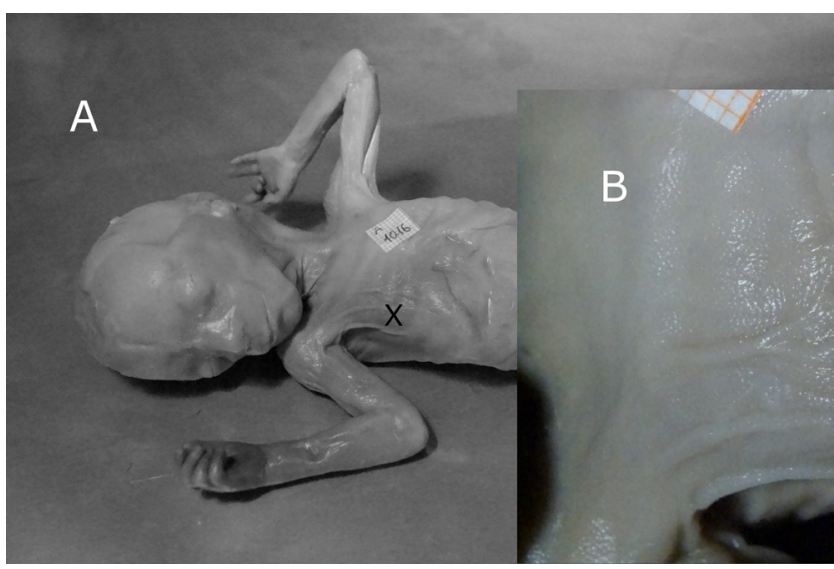

A - main picture; $X$ - the location of the enlarged area; $B$ - the enlarged area (magnification: $\mathbf{x} 4.1$ ).

Fig. 6. A photo of a fetus with trace hair (fetus no. A-468, morphological age: 6 months after conception)

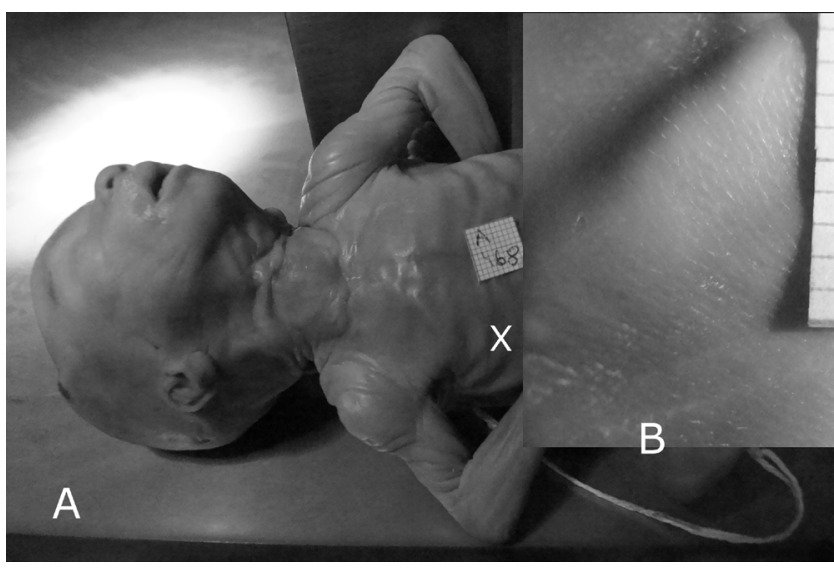

A - main picture; $X$ - the location of the enlarged area; $B$ - the enlarged area (magnification: $\times 4.5$ ) showing the hair pattern.

Fig. 7. A photo of a fetus with a "thoracic delta" pattern (fetus no. A-871, morphological age: 6 months after conception)

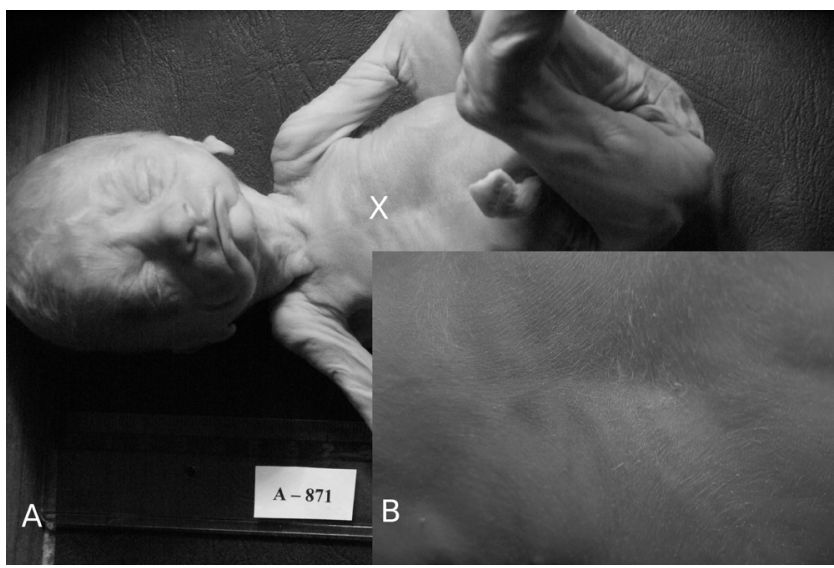

A - main picture; $X$ - the location of the enlarged area; $B$ - the enlarged area (magnification: $\times 4.1)$ showing the hair pattern.
Fig. 8. A photo of a fetus with a "vertebral column path" pattern (fetus no. A-474, morphological age: 6 months after conception)

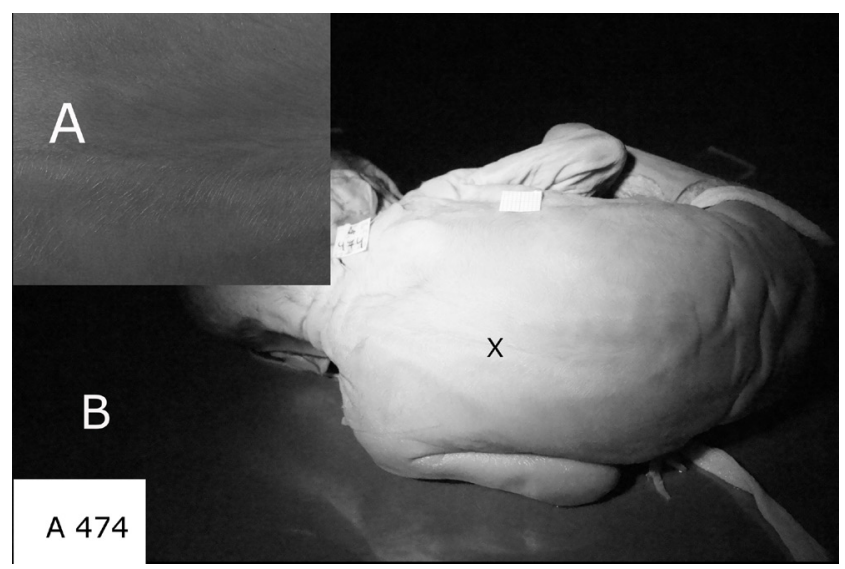

A - main picture; $X$ - the location of the enlarged area; $B$ - the enlarged area (magnification: $\times 3.2$ ) showing the hair pattern.

\section{Discussion}

The appearance of lanugo on human skin is determined by the developmental processes during embryogenesis. The first stage of this process is the creation of rudimentary hair follicles, starting with the organization of epidermal keratinocytes into hair placodes. This is followed by the accumulation of specialized fibroblasts with inductive properties in the underlying mesenchyme. ${ }^{12}$ The hair buds that are formed by quickly proliferating epidermal cells bulging towards the mesenchyme begin to appear around the $8^{\text {th }}$ or $9^{\text {th }}$ week of fetal development. Their development and maturation is controlled by various signalling substances such as lymphoid enhancer factor 1 (LEF-1), bone morphogenic protein 4 (BMP4) and transforming growth factor beta (TGF-beta). These substances are responsible for hair growth dynamics and for the correct order of development of the individual elements. The main gene controlling the in-growth of the growing hair papilla is the hedgehog gene, which codes the polypeptide, singaling ligand of the hedgehog signaling pathway. It probably plays a key role in the fusion of the ectodermal part of a hair with the mesenchyme. ${ }^{13}$

Single hair follicles are very precisely located within the developing skin. Their position is a result of interactions between Wnt proteins and beta-catenin. ${ }^{14}$ These relations are the reason why the hair follicles that begin to appear on the human fetus skin at around the $10^{\text {th }}$ week after fertilization are equidistant from each other. Further maturation of the hair follicle is the effect of the interaction among various chemical factors. As a result of the whole multistage process, approx. 5 million hair follicles are created. Paus and Cotsarelis suggested that new hair follicles are not subsequently created and that observed hair changes are the result of the influence of hormonal factors on hair follicles located in various parts of the human body. ${ }^{15}$ 
According to the literature, the time lanugo appears on human fetuses is specified at the $18^{\text {th }}-20^{\text {th }}$ gestational week. ${ }^{14,16}$ In 1921 Ludwig also indicated that lanugo patterns become "clear and explicit" in the $5^{\text {th }}$ month of fetal life. ${ }^{7}$

The present study shows that the first single hairs appear on the posterior wall of the trunk in the $17^{\text {th }}$ gestational week, and on the anterior wall between the $18^{\text {th }}$ and $19^{\text {th }}$ gestational weeks. Plikus and Chuong suggested that the first developmental hair cycle in a mammal's life starts in the cephalic part of the mammal, then "wanders" distally, first to the back, then the abdomen and finally reaching the limbs. They referred to this process as "the developmental wave". ${ }^{17}$ The same researchers, whose findings are based on the studies of genetically modified mice, indicated that this mechanism is responsible for the creation of hair whorls, and that it is a result of the activity of various genes and epigenetic factors discovered during an analysis of the Drosophlila melanogaster genome.

The results of the present study confirm the suggestions of Plikus and Chuong, revealing a statistically significant difference in the timing of lanugo appearance in humans. Hair streams first become visible on the dorsum, and then appear on the abdominal wall. The difference in actual time is almost 2 gestational weeks. No other differences in the lanugo developmental cycle were observed.

The developmental cycle, consisting first in the appearance of single hairs, then incomplete patterns and finally complete lanugo patterns, is equivalent on the anterior and posterior walls of the trunk. The first complete pattern was observed in the $19^{\text {th }}$ gestational week on the posterior trunk wall, and in the $21^{\text {st }}$ week on the anterior wall. Complete lanugo patterns were observed in $100 \%$ of the examined fetuses on the dorsal side in the $23^{\text {rd }}$ gestational week, and on the ventral side in the $26^{\text {th }}$ gestational week.

Verification of the "developmental wave" theory in humans will be possible shortly, because the present authors are currently carrying out a study evaluating the morphology of fetal pilosity within the head and neck.

\section{Conclusions}

The developmental cycle, consisting first in the appearance of single hairs, then incomplete patterns and finally complete lanugo patterns, is equivalent on the anterior and posterior walls of the trunk.

The first single hairs appear on the posterior wall of the trunk in the $17^{\text {th }}$ week of fetal life, and on the anterior wall between the $18^{\text {th }}$ and $19^{\text {th }}$ weeks.

It was found that lanugo development was complete on the back in the $23^{\text {rd }}$ week and on the abdomen in the $26^{\text {th }}$ week.

\section{References}

1. Krupiński T. Badania nad przebiegiem owłosienia karku u człowieka. MiPA. 1977;93:41-48.

2. Plikus M, Chuong CM. Making waves with hairs. J Invest Dermatol. 2004;122:vii-ix.

3. Widelitz RB, Baker RE, Plikus M, et al. Distinct mechanisms underlie pattern formation in the skin and skin appendages. Birth Defects Res C Embryo Today. 2006;78:280-291.

4. Tomkins L, Mcgreevy P. Hair whorls in the dog (Canis familiaris). I Distribution Anat Rec. 2010;293:338-350.

5. Kurlej W, Alda-Woyczys R. Badania nad przebiegiem owłosienia karku u płodów. MiPA. 1990;111:81-90.

6. Gworys B, Domagala Z. The typology of the human fetal lanugo on the thorax. Ann Anat. 2003;185:383-386.

7. Ludwig E. Morphologie und Morphogenese des Haarstrichs. Z Anat Entw Gesch. 1921;62:59-152.

8. Muller M, Jasmin JR, Monteil RA, Loubiere R. Embryology of the hair follicle. Early Hum Dev. 199;26:159-166.

9. Irmak MK, Oztas E, Vural H. Dependence of fetal hairs and sebaceous glands on fetal adrenal cortex and possible control from adrenal medulla. Med Hypotheses. 2004;62:486-492.

10. Woźniak J, Kędzia A, Dudek K. Assessment of foetal age on the basis of the selected dimensions of the thorax. Adv Clin Exp Med. 2014;23:805-811.

11. Kędzia A, Janeczko M, Miśkiewicz K, Dudek K. Morphometry of human musculus gluteus maximus in foetal period. Adv Clin Exp Med. 2014;23:9-16.

12. Schmidt-Urlich R, Paus R. Molecular principles of hair follicle induction and morphogenesis. Bioessays. 2005;27:247-261.

13. St-Jacques B, Dassule HR, Karavanova I, et al. Sonic hedgehog signaling is essential for hair development. Curr Biol. 1998;24:10581068.

14. Gareri J, Koren G. Prenatal hair development: Implications for drug exposure determination. Forensic Sci Int. 2010;196:27-31.

15. Paus R, Cotsarelis G. The biology of hair follicles. N Engl J Med. 1999;341:491-497.

16. Larson BJ, Longaker MT, Lorenz HP. Scarless fetal wound healing: A basic science review. Plast Reconstr Surg. 2010;126:1172-1180.

17. Plikus $M$, Chuong CM. Complex hair cycle domain patterns and regenerative hair waves in living rodents. J Invest Dermatol. 2008;128:1071-1080. 